\title{
Analysis of the Effect of Electronic Document Management System, Organizational Commitment and Work Satisfaction on Employee Performance PT. Graha Fortuna Purnama
}

\author{
Rahmat Andriansyah \\ Mercu Buana University \\ Jakarta, Indonesia
}

\author{
Farida Elmi \\ Mercu Buana University Jakarta, Indonesia
}

\begin{abstract}
The main problem of this study is the ineffectiveness of the workings of employees of PT. Graha Fortuna Purnama which is marked by the low performance of employees due to the fact that there are still employees who do not understand how to use the EDMS (Electronic Document Management System) system properly. This is presumably due to the company's lack of commitment to achieving its goals because employee job satisfaction has not been created to the maximum. This research method using a quantitative approach, with a population of EDMS application users is an employee of 203 employees, an engineering random sampling method and set aside a sample of 134 employees. Data analysis techniques used in this research are by using multiple linear regression analysis, which aims to test the effect of multiple independent and dependent variables. It is also used to obtain the results that are valid and reliable data that can be used to solve the existing problems in the company. From these results obtained results that EDMS, organizational commitment, job satisfaction together with a significant effect on the performance of employees of PT. Graha Fortuna Purnama. The conclusions obtained by EDMS, organizational commitment, job satisfaction empirically have an effect on employee performance either partially or simultaneously. Suggestions are given so that companies further improve employee performance by conducting training, education, and outreach about the importance of EDMS.
\end{abstract}

Keywords:- EDMS, Organizational Commitment, Job Satisfaction, Employee Performance.

\section{INTRODUCTION}

The development of information technology has developed extraordinary both in terms of hardware, software or human resources to use.

Nowadays, human life begins to shift to the life of persuasive computing, a life that puts information technology as part of human life anytime and anywhere.
This can be seen from human behavior to get used to using a digitizing system, with the use of the Internet as a tool to search for information.

The technology developed at this time is not only able to help or help in business information centers but can help companies in data storage, for that there is a lot of competition between companies, making the company continue to innovate in improving employee work performance more effectively and efficiently by using a Management System Electronic Document or EDMS (Electronic Document Management System).

At this time there are still many companies using traditional systems were using paper as a document, it makes a lot of expenses incurred by companies to buy paper, printer ink, or data storage cabinets, which will make the company inefficient. Some of the deficiencies that occur when the company is still storing documents using paper, such as the possibility of an employee forgetting to print and archive documents, or electronic documents erased from a computer without previously being archived even existing documents can not manage multimedia documents (text, images or sound) in an integrated manner. Although now there are several companies that use data storage through software such as e-mail, web pages, and database packages stored on the server. However, it is very much needed an application that can manage these documents and help the process of acceleration in the search for data so as to improve employee performance more effectively and efficiently in terms of cost, time and energy.

Electronic Document Management System or EDMS (Electronic Document Management System) is a technology application to save paper and speed up communication and increase the productivity of business operations. From a broader perspective, EDMS is a significant expansion in the field of information management and the increasing responsibilities of managers and executives (Zantout \& Marir 1999). The existence of an EDMS system can facilitate company management in collecting data, which is integrated into an organization or corporate organization. This electronic document management system (EDMS) is the most necessary requirement for management in a company. 
Some of the problems above (EDMS) are the most needed tools for management. One company that uses the EDMS system is PT. Graha Fortuna Purnama.

PT. Graha Fortuna Purnama is a company engaged in the procurement of goods, focusing its business on the production of goods that are sold to other parties for an object or item. For that, it needs a system that makes it easy for employees to obtain information data quickly and precisely. The phenomenon that often occurs that EDMS gets a negative spotlight to create, maintain, and organize data, in organizations and handle all synchronization because mismatches between reality and procedures still often occur. In fact, until now, there are still many who have not utilized information technology, rather than the electronic document management system in maintaining their documents.

This performance issue is not only detrimental for companies to get out of trouble. Employees who are physically present also bring an important role in achieving the work of the Organization. Human Resouce departement (HRD) that often deal with it, especially how to use the best way to provide organizational commitment to the needs, and the desire of employees so that no party feels harmed so that it has a positive impact for employees and organizations.

In the same year in the years 2016 and 2017, there were no employees at all to get quality management. Therefore, some of the organizational commitments that employees follow are not particularly relevant to the fields and competencies of the employees that follow them.

In addition, the organizational commitment has not been perceived evenly by employees who are balanced, so the opportunity for employees to increase their competence and ability to be hampered. This condition can potentially impact the loss of capacity development opportunities and knowledge to improve the capacity and capability of employees.

The assumed organization or company commitments will improve employee performance. The improvement in employee performance is expected to increase the productivity of the company, which will eventually reach the company's goal of obtaining an optimal profit. The advancement of electronic document management system and employee satisfaction is also a separate motivation from each employee. From the explanation, there has been much research done in the field of human resources related; Electronic document management system, organizational commitment and job satisfaction. This is the following, among others.

According to previous research on electronic document management system done Khairymusttafa Said Kittanah, Saharfaleha wadabujarour, and Amman Jordan (2016). The study title of The Impact of Electronic Document Management on Performance, stating that The Electronic document management system has no significant effect on the employee's performance. Previous research on the organizational commitments undertaken by K. Metin and K. Asli (2018). The Research title The Relationship between Organizational Commitment and Work Performance: A Case of Industrial Enterprises, stated that the organizational commitment has no significant influence on employee performance.

\section{LITERATURE REVIEW}

\section{A. Electronic Document Management System (EDMS)}

Electronic Document Management System (EDMS) is a system that uses electronic media as a file storage facility, which has been digitized and has a search facility to make it easier in the process of obtaining results.

According to Andreas Holzinger (2009:2.37), EDMS is any form of digital file that only contained in electronic forms/formats such as data stored on computers, networks (Network), back-ups into Compact disks (CDS) or DVDS, or other storage media. Examples of document forms can be: email, voice mail, massage instances (IM), e-Calender, audio-Files, video, mobile data transfer results, animations, graphics, photo presentation, Web pages, and other digital data.

According to Hendi Haryadi (2009:53), an EDMS or Electronic Document Managent System indicator is as follows: Data, Hardware (Hardware), Software, human resources, procedures for archival systems, communication networks.

\section{B. Organizational Commitment}

Organizational Commitment is the strength of individual identification and engagement with the organization. The attitude of employees to remain fully engaged in an organization, which has a high attachment to the achievement of mission, vision and values in the organization.

According to Mathis (2000), as quoted by Sopiah (2008:155), mentions that "Organizational commitment is the degree to which employess believe in and accept Organizational goals and desire to remain with the organization" (the organizational commitment as a degree where employees believe and want to accept organizational objectives and will remain/will not elevate their organization. Furthermore, according to Steers (1982) in Sri Kuntjoro (2009:50), the organizational commitment is a sense of identification (trust in organizational values), engagement (a willingness to best in the Organization for the benefit of the organisation) and loyalty (the desire to remain a member of the organization in question) expressed by an officer on its organization.

McShane and Von Glinow (2008:119), mentioning the organizational commitment is the strongest influence, which people identify on demand and are highly motivated to perform, even when the source of motivation is no longer present. Highly committed employees will have high productivity (Luthans, 2002). Conversely, low employee 
commitments have a negative impact. Each organization will have difficulties if its employees ' commitments are low. Employees with a low commitment will not give the best to the organization and easily exit the Organization (Riady, 2003). Based on the definitions above, it can be concluded that the Organization's commitment is an individual process to stay on top of the decision involving the work and its future, and subsequently emerge as a value for the efforts of the company.

Factors influencing the commitment of the Organization, McShane and Glinow (2000) quoted Wibowo (2015:433) are as follows:

> Justice and Support

Fulfill obligations on workers and stay with humanitarian values such as honesty of honor, willingness of forgiveness and moral integrity. Organizations that support worker welfare tend to reap higher loyalty rates.

\section{Shared Values}

The workers are comfortable and confident in the organization's values. When they agree with the values underlying corporate decisions.

\section{Trust}

Trust shows one person's positive expectations towards others in situations involving risk. Belief means placing fate on another person or group.

\section{Organizational Comprehension}

Organizational understanding shows that how well workers understand the organization, including strategic direction, social dynamics, and physical spatial.

\section{$>$ Employee Involvement}

Worker Agility reinforces the social identity of workers with organizations. Workers feel that they are part of the organization when they participate in decisions that direct the organization's future.

According to Lincoln (1989) and Bashaw (1994) quoted by Sopiah (2008:156) suggests an organizational commitment indicator there are three, namely: 1. employee willingness, 2. employee loyalty, and 3. employee pride in the organization.

\section{Job Satisfaction}

Job satisfaction in the meaning of the Dictionary of the Indonesian Nation (KBBI), In addition to satisfied with the work, covers satisfaction of the work environment. Job satisfaction, is an important thing that individuals have in the works. Each individual works has different characteristics and the satisfaction level of work also varies.

According to Sopiah (2008:170), that job satisfaction is "Job Satisfaction is a pleasurable or positive emotional state resulting from the appraisal of one's job or job experience," or who expressed satisfaction is an emotional expression that is Positive or enjoyable as a result of the assessment of a work or work experience.
According to Hasibuan (2014:203) Job satisfaction is an emotional attitude that pleases and loves his work. This attitude is reflected by work morals, discipline, and job performance.

This job satisfaction is enjoyed in work, outside work and combination, in and out of work. Based on the understanding described about job satisfaction. It can be concluded that job satisfaction is an portrayed as the employee looks at the awards and benefits they have received, and that is the attitude of an employee in the workplace.

The theory that discusses the work satisfaction is commonly called need based theories (which focuses on reducing the shortage that employees have and identifying the needs of employees needed).

> Hierarchy needs Maslow, according Maslow theory (2016:6), human needs can be divided into 5 (five) Categories:

- Physiological Needs

The first category is the basic human need to avoid thirst and hunger.

\section{- Safety Needs}

The second category for example is job certainty.

\section{- Social Needs}

The third category deals with support, social acceptance, love and friendship.

\section{- Egotistical Needs}

The fourth category relates to humans needs to be respected.

\section{- Self-actualization}

In the last and highest category is the need of officers in conducting self-actualisation, to achieve their maximum potential.

\section{$>$ Herzberg's Two FactorTheory}

According to Herzberg's theory, the concept of theory separates between satisfaction and job dissatisfaction, as it is considered controversial with the basic assumption that is always used.

- Hygiene factors as lower order needs

What is included in the factors are salary, working environment, job status, interpersonal relationship

- Motivators as higher orderneeds

Included in the factors are challenges, responsibilities, achievement, and promotion opportunities. 
According to Zainal (2014:623), the job satisfaction indicator is as follows:

- Job content

- Supervision

- Organization or management

- Opportunity to progress

- Work Guarantee

- Co-workers

- Occupational conditions

\section{Performance}

Performance is an overall outcome or success rate for a given period in carrying out a task compared to a variety of possibilities, such as a standard of work, target or target, or predefined criteria First and has been agreed together. According to Moeheriono (2012:95), it is said that performance or performance is a depiction of the level of achievement of an activity program or policy in realizing the objectives, objectives, vision and mission of the organization that is poured through Organizational strategic planning.

According to Lijan Poltak Sinambela (2012:5), that employee performance is the ability of employees to do things. Results of work achieved by a person or group of people in an organization in accordance with their respective authorities and responsibilities, in order to legally achieve the objectives of the relevant organization, do not violate the law and in accordance with morals and ethics. Based on some of the above-mentioned definitions, the author symbolizes that employee performance is a result of quality work processes and also quantity, which is generated in the ability of an individual or group Skillbased experience, ability, and maximum time.

According to Wibowo (2011:229), that measurement of performance needs to be performed to determine whether during performance implementation there is a deviation from a predetermined plan, or whether performance can be performed on a prescribed schedule, or Performance results have been achieved as expected. Thus, to perform an assessment it is necessary to measure performance so that there is a measure of performance.

According to Faustino Cardoso Gomes (2010:142), the performance indicators are as follows:

○ Quantity of Work

Amount of work done. The amount of work that can be reached in a certain period

\section{○ Quality of Work}

Skills in carrying out tasks. Quality achieved based on their terms and suitability and readiness

\section{Job Knowledge}

Extensive knowledge about work. Extensive knowledge about skills

\section{Creativeness}

Idea skills. The ability to solve problems that arise
Cooperation

Willingness to cooperate with employers

Willingness to work with colleagues

Depentability

Awareness in terms of attendance. Can be trusted in terms of presence

\section{Initiative}

Passion in carrying out the task. The spirit of doing responsibility.

\section{Personal Qualities}

Leadership. Personal integrity.

\section{E. Theoretical framework}

Based on the results of previous research studies on the effect of electronic document management systems, organizational commitment and job satisfaction on employee performance. Systematically in this writing can be described as follows:

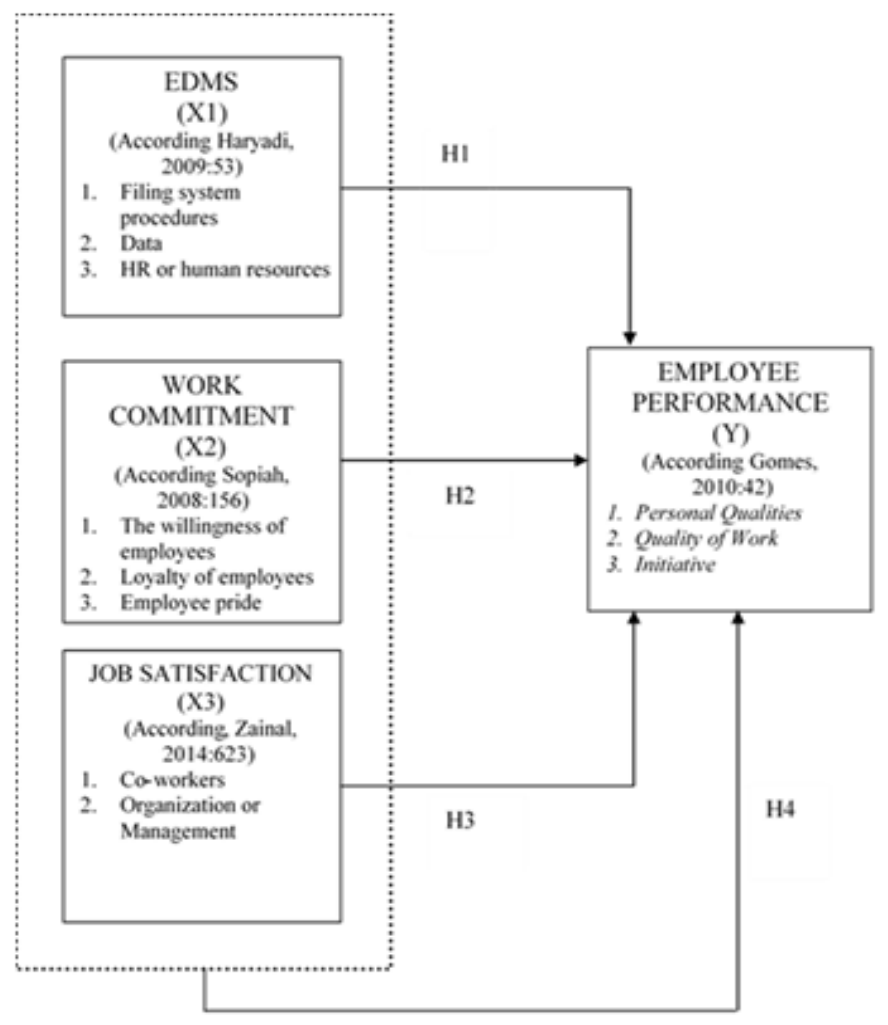

Fig 1:- Framework

\section{F. Hypothesis}

According to Sugiono (2016: 64), the hypothesis can be defined as a temporary answer to the formulation of research problems.

H1: Allegedly electronic document management system influences employee performance.

$\mathrm{H} 2$ : Allegedly organizational commitment affects employee performance.

H3: Allegedly job satisfaction affects employee performance. 
H4: Allegedly electronic document management system, organizational commitment and job satisfaction affect employee performance.

\section{METHODOLOGY}

This study uses a survey method, namely the collection of information carried out by compiling a list of questions raised by respondents and extracting data through a questionnaire and then processed through the SPSS (Statistical Package for the Social Sciens) program.

Research with this method is carried out with the aim of obtaining primary data. So, this study describes the Analysis of the Effect of Electronic Document Management System, Organizational Commitment and Job Satisfaction on Employee Performance of PT. Graha Fortuna Purnama.

This research was designed using descriptive methods with a quantitative approach. Descriptive statistical methods are used to explain the phenomena that occur regarding research data. While quantitative methods are used to explain the effect of independent variables on the dependent variable in this study.

In this case the study uses 3 (three) independent variables, namely EDMS, Organizational Commitment, Job Satisfaction, and 1 (one) dependent variable, namely Employee Performance.

The study was conducted at PT. Graha Fortuna Purnama, the population in this study were all employees of EDMS users, amounting to 203 employees. The sampling technique uses the random side method with Slovin formula so that a sample of 134 employees is obtained.

The data analysis technique used in this study is by using multiple linear regression analysis.

\section{RESULTS AND DISCUSSION}

\section{A. Hypothesis test}

In this study an analysis of the influence of EDMS and organizational commitment and job satisfaction was analyzed on Employee Performance.

\section{B. Multiple Determination Coefficient Analysis.}

Multiple determination coefficient analysis is an analysis used to find out how much influence the EDMS and organizational commitment and job satisfaction together on Employee Performance.

Model Summary

\begin{tabular}{|c|c|c|c|c|}
\hline Model & $\mathbf{R}$ & $\begin{array}{c}\text { R } \\
\text { Square }\end{array}$ & $\begin{array}{c}\text { Adjusted R } \\
\text { Square }\end{array}$ & $\begin{array}{c}\text { Std. Error } \\
\text { of the } \\
\text { Estimate }\end{array}$ \\
\hline $\mathbf{1}$ &, $899^{\mathrm{a}}$ &, 808 &, 803 & 2,559 \\
\hline
\end{tabular}

Table 1:- Determination Test Results a. Predictors: (Constant), Job Satisfaction, EDMS, Organizational Commitment

b. Dependent Variable: Employee Performance

Based on Table 1 by looking at the R Square figure of 0, $808 \mathrm{R}$ Square Number $\mathrm{R}$ is also called the Multiple Determination Coefficient. The amount is 0.808 or equal to $80.8 \%$. So, it can be concluded that the influence of EDMS and Work Commitment and Job Satisfaction together on employee performance is $80.8 \%$, while the rest can be explained by other causative factors. In this study, it means that other factors that influence employee performance are predicted to be smaller. This means that the chosen variable is appropriate enough.

\section{Multiple Regression Coefficient Analysis.}

This section describes the regression equation to find out the constant numbers and test the hypothesis of the regression coefficient significance.

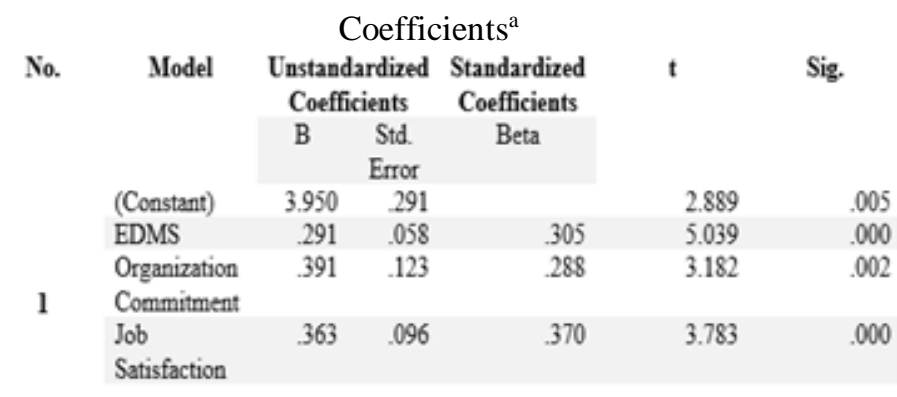

Table 2:- Regression Test Results

a. Dependent Variable: Employee Performance

Based on the results of data analysis conducted using SPSS version 25, the following form of multiple linear regression has been obtained:

$\mathbf{Y}=\mathbf{a}+\mathbf{b X 1}+\mathbf{b X 2}+\mathbf{b X 3}$

$Y=3.950+0,291 X 1+0,391 \times 2+0,363 X 3$

Based on the results of the equation it can be explained that:

$>$ Constants (a) $=3,950$, showing the amount of employee performance, if the electronic document management system, organizational commitment and job satisfaction are zero, then the amount of employee performance is 3,950.

> EDMS or electronic document management system (X1) regression coefficient of 0.291 , indicating the magnitude of the influence of the electronic document management system on employee performance, the regression coefficient that is positive indicates the electronic document management system has a direct effect on employee performance, which means that every time there is an increase in EDMS will be followed by an increase in employee performance at PT. Graha Fortuna Purnama by $29.1 \%$. Vice versa, if EDMS has decreased the performance of employees of PT. Graha Fortuna Purnama will also experience a decrease of $29.1 \%$. The value of $t$ arithmetic was 5.039 with a significance of $t$ intrinsic motivation of 0,000 
$<0.05$, with a very weak correlation of SC $\beta 1(0.305)$. Thus it is evident that the electronic document management system (X1) variable has a significant effect on employee performance (Y). Thus the first hypothesis can be accepted.

$>$ Organizational commitment regression coefficient (X2) of 0.391 , indicating the magnitude of the effect of organizational commitment on employee performance, the regression coefficient that is positive indicates organizational commitment has a direct effect on employee performance, which means that any increase in organizational commitment will be followed by an increase in employee performance in PT. Graha Fortuna Purnama by $39.1 \%$. Vice versa, if EDMS has decreased the performance of employees of PT. Graha Fortuna Purnama will also experience a decrease of $39.1 \%$. T value of 3.182 with the significance of intrinsic motivation $\mathrm{t}$ of $0.002<0.05$, with a fairly strong correlation of SC $\beta 2(0.288)$. Thus it is proven that organizational commitment variable (X2) has a significant effect on employee performance (Y). Thus the second hypothesis can be accepted.

\section{Hypothesis F-test.}

The effect of all independent variables on employee performance has a significant value. This means that the Transformational Leadership Style and Work Discipline and Work Placement greatly affect Employee Performance.

\begin{tabular}{|c|c|c|c|c|c|c|}
\hline \multicolumn{7}{|c|}{ ANNOVA $^{\mathrm{a}}$} \\
\hline No. & Model & $\begin{array}{l}\text { Sum of } \\
\text { Squares }\end{array}$ & df & $\begin{array}{l}\text { Mean } \\
\text { Square }\end{array}$ & $\mathbf{F}$ & Sig. \\
\hline \multirow{4}{*}{1} & Regression & 3573,246 & 3 & 1191,082 & 181,825 & $.009 \%$ \\
\hline & Residual & 851,590 & 130 & 6,551 & & \\
\hline & Total & 4424,836 & 133 & & & \\
\hline & & Table & Tes & & & \\
\hline
\end{tabular}

a. Dependent Variable: Employee Performance

b. Predictors: (Constant), Job Satisfaction, EDMS, Organizational Commitment

Based on Table 3 above the Anova Test was obtained or the F count was 181,825 with a significant level of 0,000 . Because the significant value of 0,000 is smaller than 0.005 , it can be said that the electronic document management system, organizational commitment, job satisfaction together affect the performance of employees.

\section{* Discussion}

Based on the results of the first hypothesis testing, it can be concluded that there is a positive and significant effect between EDMS and Employee Performance at PT. Graha Fortuna Purnama. This is proven by Ho being rejected and Ha being accepted or tcount greater than t table (5,039> 1,288). From the information above it can be interpreted the conditions at the time of the study that EDMS affects the Performance of Employees at PT. Graha Fortuna Purnama. EDMS includes efforts to change the filing system procedures, data and human resources to organizational commitment. Various studies conducted relating to job satisfaction, especially in relation to EDMS show that there is a significant relationship between EDMS and organizational commitment.

From the results of the second hypothesis testing it can be concluded that there is a positive and significant effect between organizational commitment and employee performance at PT. Graha Fortuna Purnama. This is proven by Ho being rejected and $\mathrm{Ha}$ being accepted or tcount greater than $t$ table (3.182> 1.288). From the information above, it can be interpreted the conditions at the time of the study that organizational commitment affects the Employee Performance of PT. Graha Fortuna Purnama. The above results prove that organizational commitment has an important meaning for employee satisfaction with organizational commitment to employees, then within the company will make the company become advanced, because the company in carrying out its commitments properly will build employee willingness, employee loyalty to the company so that employees will have pride in the company.

From the results of testing the third hypothesis it can be concluded that there is a positive and significant effect between job satisfaction with Employee Performance at PT. Graha Fortuna Purnama. This is proven by Ho being rejected and Ha being accepted or tcount greater than t table $(3,783>1,288)$. From the information above it can be interpreted the conditions at the time of the study that job satisfaction affects the Performance of Employees at PT. Graha Fortuna Purnama. These results prove that the job satisfaction process is a very decisive process in motivating employees both encouragement from coworkers because a good colleague environment and the role of the company in providing good training and education will make employees competent to improve the performance needed by the company, because good performance and increasing can help companies achieve their expected goals.

Based on the results obtained, it is known that the significance value is 0,000 because the Sig value is below 0.05 , so it can be said that the three independent variables simultaneously influence employee performance. As for testing with the F Test, the Fcount value of 181,825 and FTabel is 2.696 thus found the results of Fcount> FTabel then $\mathrm{H} 0$ is rejected and $\mathrm{H} 1$ is accepted. It can be concluded that simultaneously there is an influence of EDMS, organizational commitment, and job satisfaction on the performance of the employees of PT. Graha Fortuna Purnama. Where the employee's performance is basically formed after the employee feels satisfaction, because his needs are met in other words if the employee's needs have not been met as they should then job satisfaction will not be achieved, and in essence employee performance will be difficult to form. 


\section{CONCLUSIONS}

Based on the results of the discussion in the previous chapter, it can be concluded as follows:

$>$ EDMS implementation has positive and negative impacts for a company. Although the implementation of EDMS in some research literature has had mixed results that show the pros and cons as well as some challenges or obstacles in its use, the implementation of EDMS needs to be considered for a company in both the public and private sectors. This is to improve the quality of information services effectively, efficiently, accurately and transparently in accordance with the demands of current technological advancements that require information quickly that can be accessed anytime and anywhere according to their needs. In order to minimize obstacles and challenges in implementing EDMS, several things that need to be considered and done are the need for support from various internal and external parties involved in a company, collaboration between related parties is needed, the need for procurement of training, education and outreach about the importance of EDMS, it is necessary to have a feasibility study on the costs, values and benefits of EDMS, institutions need to have a document management strategy whether it is stored or destroyed, as well as supervision, monitoring, evaluation and also corrective actions carried out systematically and periodically, in addition to seeing from the company's commitment there are still many things- rights that must be improved because there are still many employees who get a lot of workload, not much is applied in their daily work, and there are still many employees who lack initiative and very low level of knowledge..

$>$ It is expected that the company's commitment is more focused, focused and more effective for the employees themselves. Because, increasing work and having an active role in the company, employees will increase their performance effectively and responsibly and can contribute to the maximum which will have a good impact on the company's profit. Then for job satisfaction there are still employees who feel unsatisfied with praise given by the company to employees for their work performance, but on the other hand job satisfaction at PT. Graha Fortuna Purnama actually occurs because the bond of fellow colleagues has a good relationship in motivating and helping fellow employees in work, besides the next biggest indicator is the provision of old age insurance provided by leaders of employees loyal to the company or achieved to be the biggest indicator which is in the factor of employee job satisfaction so that it can be concluded that the employees of PT. Graha Fortuna Purnama has great support in working because of the support between these employees in their fellow colleagues and the attention of the leadership to the guarantee of employee loyalty to the company so as to shape their performance for the better..

$>$ Performance of employees at PT. Fortuna is good enough where employees already have the ability to direct and guide other employees in working to be more effective, many employees are able to complete tasks on time as seen from the achievement of company targets that never miss, with the EDMS employees are more careful in storing document file data although sometimes there are still some employees who are still experiencing errors in work, but in addition there are still quite a lot of employees who are still unable to issue creative ideas that are more recent for the progress of the company, because it seems the company is still not able to develop rapidly in terms of digital marketing..

Based on the conclusions above, the author tries to convey some suggestions for further research.

$>$ Company management is advised to pay attention to the Electronic Document Management System (EDMS) which can increase expertise and lead to work creativity in accordance with the field of work with the field of employee work, with organizational commitment which is also expected to increase.

$>$ Company owners are advised to pay attention to organizational commitment that makes it easier for employees to cope with their work, increase the use of new technology and equipment and increase curiosity for employees so that employees are able to complete their work, in accordance with the allotted time.

$>$ The company is advised to pay attention to job satisfaction in listening to the opinions of employees, so that employees also feel valued and able to complete their work in accordance with the quality and effective work that has been determined by the company.

$>$ Company leaders are advised to pay attention to employee performance to find out the expected results of their work that are able to provide quality work. ompany leaders are advised to be able to improve their adaptability, ability to be responsible for their positions, an understanding of the company's strategy and quality of job control so that the work produced is in accordance with the quality expected by customers (internal and external).

$>$ Company leaders are advised to be able to improve their adaptability, ability to be responsible for their positions, an understanding of the company's strategy and quality of job control so that the work produced is in accordance with the quality expected by customers (internal and external).

$>$ Using other methods in examining the Effect of Electronic Document Management System, Organizational Commitment and Job Satisfaction on Employee Performance, for example through a qualitative approach, so that information and data obtained are more comprehensive.

$>$ Develop a research model by developing a more varied population and sample, so that it can be a useful input for the company.

$>$ Explore the effect of independent variables on employee performance, and involve other variables such as: organizational business processes, system integration and or factors in effective management to predict employee performance 


\section{REFERENCES}

[1]. Abdulkadhim Haider, Bahari Mahadi, Bakri Aryati, and Ismail Waidah (2015) A research framework of electronic document management systems implementation process in government. Journal of Theoretical and Applied Information Technology, 81 (3). pp. 420-431. ISSN 1992-8645.

[2]. Abraham H. Maslow. 1994. Motivasi dan Kepribadian (Teori Motivasi Dengan Pendekatan Hierarki Kebutuhan Manusia). PT PBP, Jakarta.

[3]. A. Muri Yusuf, Metode Penelitian: Metode Penelitian Kuantitatif, Kualitatif, dan Penelitian Gabungan (Jakarta: Prenada Media Group).

[4]. Andreas Holzinger, Klaus Miesenberger. 2009. HCI and Usability for e-Inclusion: 5th Symposium of the Workgroup Human-Computer Interaction and Usability Engineering of the Austrian Computer Society, USAB 2009, Linz, Austria, November 9-10, 2009, Proceedings. Austria: Spinger.

[5]. Ashari, Purbayu Budi Santoso. 2005. Analisis Statistic dengan Microsoft excel dan SPPSS. Yogyakarta.

[6]. Asogwa, B. E. (2012). The challenge of managing electronic records in developing countries: implications for records managers in sub saharan africa, Records Management Journal, 22, 198-211

[7]. Bataineh, Khaled Adnan (2017). "The Impact of Electronic Management on the Employees' Performance Field Study on the Public Organizations and Governance in Jerash Governorate". Journal of Management and Strategy Vol 8, No 5.

[8]. Bryman, A., and Bell, E. (2007). Business Research Methods. (2nd ed). Oxford University Press.

[9]. Budiman, (2009), Muhammad Rosyid. Dasar Pengelolaan Arsip Elektronik, Yogyakarta: Badan Perpustakaan dan Arsip Daerah.

[10]. Bungin, Burhan. 2013. Metode penelitian social \& ekonomi: format-format kuantitatif dan kualitatif untuk studi sosiologi, kebijakan, publik, komunikasi, manajemen, dan pemasaran edisi pertama. Jakarta: kencana prenada media goup.

[11]. Colquitt, Jason A., Lepine, Jeffery A. \& Wesson, Michael J. (2009). Organizational Behavior. Improving Performance and Commitment in the Workplace. New York : McGraw-Hill/Irwi.

[12]. Cooper, D.R. \& Schindler, P.S. (2008). Business Research Methods. Tenth Edition. New York: McGraw-Hill.

[13]. Danang, Sunyoto. (2013). Metodologi Penelitian Akuntansi. Bandung: PT Refika Aditama Anggota Ikapi.

[14]. Imam Mulyantono, M. (2012). Materi Pokok otomasi dalam Kearsipan. Tangerang Selatan: Universitas Terbuka.

[15]. Greenberg, J. And Robert A. Baron. 2008. Behavior in Organization International Edition, New Jersey: Prentice Hall.

[16]. Gomes, Faustino Cardoso, 2010, Manajemen Sumber Daya Manusia, Andi Yogyakarta.

[17]. W. Gulo. Metodologi Penelitian Jakarta: Grasindo. 2010.
[18]. Hair, Joseph F., et.al. 2010. Multivariate Data Analysis, 7th Edition. New York: Prentice Hall International, Inc.

[19]. Handoko, T Hani, (2008). Manajemen Sumber Daya Manusia, Edisi Kedua, Yogyakarta, Penerbit: BPFE.

[20]. Hasibuan, SP. Melayu. 2014. Manajemen Sumber Daya Manusia. Edisi Revisi. Jakarta: Bumi Aksara.

[21]. Hendi Haryadi. (2009). “Administrasi Perkantoran untuk Manajer \& Staf”. Jakarta: Visi media

[22]. Kuntjoro, S, Zaenuddin. (2009). Komitmen Organisasi. E-psikologi. Diperoleh dari www.epsikologi.com/epsi/search.asp. Diakses tanggal 15 September 2012.

[23]. Malhotra, M.K. (2012). Operations Management, 10th Edition. USA: Pearson.

[24]. McShane, Steven L. \& Von Glinow, Mary Ann. (2008). "Organizational Behavior". Fourth Edition. McGRAW-Hill International, United States of America.

[25]. Moeheriono. 2012. "Pengukuran Kinerja Berbasis Kompetensi”. Jakarta: Raja Grafindo Persada.

[26]. Mudrajad Kuncoro, (2013). "Metode Riset untuk Bisnis dan Ekonomi”, Edisi 4. Jakarta: Erlangga.

[27]. Mulyanto. Agus, "Sistem Informasi Konsep dan Aplikasi”, Yogyakarta: Pustaka Pelajar, 2009.

[28]. Munandar A.S. 2001. Psikologi Industri dan Organisasi. Jakarta: UI-Press.

[29]. Nugroho, Bhuono Agung. 2011. Strategi Jitu: Memilih Metode Statistik Penelitian dengan SPSS. Yogyakarta: ANDI.

[30]. Prasetyarini, Aryati. 2005. “Alur Susunan Kalimat pada Paragraf yang Dikembangkan oleh Mahasiswa Jurusan Bahasa Inggris". Penelitian Humaniora, 2005 nomor 2 vol. 6 .

[31]. Potter, P.A., \& Perry, A.G. 2005. Buku Ajar Fundamental Keperawatan: Konsep, Proses dan Praktis. (Renata Komalasari, et al, Penerjemah). Ed. Ke-4. Jakarta: EGC.

[32]. Oei. Istijanto. (2013). Riset Sumber Daya Manusia: cara praktis mengukur stress, kepuasan kerja, komitmen, loyalitas, motivasi kerja sama dan aspek kerja karyawan lainnya. Jakarta: PT. Gramedia PustakaUtama.

[33]. Ridwan, (2010). Dasar-Dasar Statistika. Bandung : Alfa beta.

[34]. Robbins, Stephen P \& Judge, Timothy A. 2013. Organizational Behavior Edition 15. New Jersey: Pearson Education.

[35]. Schermerhorn, John R.j. 2008. Managing Organizational Behavior. Fourt Edition, John Willey and Sons, Inc.

[36]. Sekaran, Uma. (2011). Research Methods for business Edisi I and 2. Jakarta: Salemba Empat.

[37]. Sinambela, Lijan Poltak (2012-5). "Kinerja Pegawai; Teori, Pengukuran, dan Implikasi”. Yogyakarta: Graha ilmu.

[38]. Sopiah. 2008. Manajemen Sumber Daya Manusia. PT. Ghalia Indonesia, Jakarta. 
[39]. Steve Jones (2012), “eGovernmen Document Management System: A case analysis of risk and reward", International Journal of Information Management, Vol. 32 No. 4, pp. 396-400.

[40]. Sudarmanto, Kinerja dan Pengembangan Kompetensi SDM, Yogyakarta: Pustaka Pelajar, 2009.

[41]. Sugiyono. (2016). Metode Penelitian Kuantitatif, Kualitatif dan R\&D. Bandung: PT Alfabe.

[42]. Umar, Husein. 2011. Metode Penelitian untuk Skripsi dan Tesis Bisnis. Edisi Kedua. Cetakan Kesebelas. Penerbit : PT. Raja Grafindo Persada.

[43]. Wirawan. 2010. Konflik dan Manajemen Konflik: Teori. Aplikasi, dan Penelitian. Jakarta: Salemba Humanika.

[44]. Zainal, Veithzal Rivai (et. al.). 2014. Manajemen Sumber Daya Manusia untuk Perusahaan. Jakarta: PT Raja Grafindo Persada. 